\title{
American Jurisprudence Through English Eyes: The Nightmare and the Noble Dream
}

H.L.A. Hart

Brasenose College, Oxford University

\section{Repository Citation}

Hart, H.L.A., "American Jurisprudence Through English Eyes: The Nightmare and the Noble Dream" (1977). Sibley Lecture Series. 33.

https://digitalcommons.law.uga.edu/lectures_pre_arch_lectures_sibley/33

This Article is brought to you for free and open access by the Lectures and Presentations at Digital Commons @ University of Georgia School of Law. It has been accepted for inclusion in Sibley Lecture Series by an authorized administrator of Digital Commons @ University of Georgia School of Law. Please share how you have benefited from this access For more information, please contact tstriepe@uga.edu. 


\section{GEORGIA LAW REVIEW}

VOLUME 11

SEPTEMBER 1977

NUMBER 5

\section{AMERICAN JURISPRUDENCE THROUGH ENGLISH EYES: THE NIGHTMARE AND THE NOBLE DREAM*}

\section{H.L.A. Hart**}

I $t$ is with some sense of audacity that $I$ venture to address an American audience on the theme of American jurisprudence. You may well think that justice could not possibly be done to so huge a subject in the confines of a single lecture, and that if it is to be done at all, it is for an American and not for a visiting Englishman to do it. I confess I have no very convincing answer to this objection except to say that there are important aspects of even very large mountains which cannot be seen by those who live on them but can be caught easily by a single glance from afar.

Of course I recognise that there is need for caution. In The American Scene, the greatest of your country's novelists, Henry James, remarks that "the seer of great cities is liable to easy error, I know, when he finds this, that or the other caught glimpse the supremely significant one ...."This is a warning against hasty generalisation and oversimplification, and surely the warning is salutary, for, vast and various as it is, America has often tempted European observers to characterise some area of American life or thought in terms of a single salient feature presenting a strong contrast with Europe. And I confess I find myself strongly inclined to surrender to just this temptation and to characterise American jurisprudence, that is, American speculative thought about the general nature of law, by telling you in unqualified terms that it is marked by a concentration, almost to the point of obsession, on the judicial process, that is, with what courts do and should do, how judges reason and should reason in deciding particular cases. And I could quote

* The third John A. Sibley Lecture in Law for the academic year 1976-77, delivered at the University of Georgia School of Law on April 14, 1977.

** Principal, Brasenose College, Oxford University. M.A., F.B.A., Oxford University.

' H. James, The American Scene 99-100 (1907). 
in support of this the most prominent American jurists over the last eighty years. Thus Justice Oliver Wendell Holmes in 1894 said, "The prophecies of what the courts will do in fact, and nothing more pretentious, is what I mean by the law."2 The great Harvard lawyer John Chipman Gray at the turn of the century wrote, "The Law of the State or of any organized body of men is composed of the rules which the courts, that is, the judicial organs of that body, lay down for the determination of legal rights and duties." 3 A later jurist, Karl Llewellyn, in 1930 said, "What these officials [that is, mainly judges] do about disputes, is, to my mind, the law itself." And only a few years ago Professor Jaffe of Harvard said, while lecturing to us in Oxford, that the question, what is the function of the judiciary in a democratic state, was tearing at the vitals of American law faculties. ${ }^{5}$ But great areas of thought are not to be assessed by aphorisms torn from their context, and remembering Henry James' warning, I shall, in devoting most of this lecture to the concentration of American thought on the judicial process, claim only that this is one salient feature of American jurisprudence contrasting strongly with our own.

The simple explanation of that concentration is, no doubt, the quite extraordinary role that the courts, above all the United States Supreme Court, play in American government. In de Tocqueville's famous words, "scarcely any political question arises in the United States that is not resolved, sooner or later, into a judicial question." An English lawyer notes that two things have secured for the Supreme Court a role and a status unlike that of any English court and indeed unlike any courts elsewhere. The first was of course the Supreme Court's own decision that it had power to review and declare unconstitutional and so invalid enactments of Congress as well as of the state legislatures. ${ }^{7}$ The second was its doctrine that the clause of the fifth amendment, and the later fourteenth amendment, providing that no person should be deprived of life, liberty, or property without due process of law, referred not merely to matters of form

${ }^{2}$ Holmes, The Path of the Law, in O.W. Holmes, Collected Legal Papers 173 (1920).

3 J.C. Gray, The Nature and Sources of the Law 84 (2d ed. 1921).

- K. Llewellyn, The Bramble Bush 3 (1930). But see the retraction in the second edition of these words as "unhappy" and "at best a very partial statement of the whole truth." Id. at 9 (2d ed. 1951).

5 L. JaFfe, English and American Judges as Law Makers 9 (1969).

- 1 A. De Tocqueville, Democracy in America 280 (P. Bradley ed. 1945).

' See McCulloch v. Maryland, 17 U.S. (4 Wheat.) 316 (1819); Marbury v. Madison, 5 U.S. (1 Cranch) 137 (1803). 
or procedure but also to the content of legislation, so that, to an English lawyer's astonishment, even a statute of Congress of impeccable clarity, passed by an overwhelming majority and conforming to all procedural requirements specified in the Constitution, might still be held invalid because its interference with individual liberty or with property did not satisfy the requirement of a vague undefined standard of reasonableness or desirability, a doctrine which came to be called "substantive due process."

This doctrine, once adopted, secured for the power of review a vast scope and set the American courts afloat on a sea of controversial value judgments, and it became plain that in exercising these wide powers to monitor not only the form and formalities of legislation but also its content, the courts were doing something very different from what conventional legal thought in all countries conceives as the standard judicial function: the impartial application of determinate existing rules of law in the settlement of disputes. And what the courts were doing seems to the English lawyer, at first sight at any rate, particularly hard to justify in a democracy.

In fact the most famous decisions of the Supreme Court have at once been so important and so controversial in character and so unlike what ordinary courts ordinarily do in deciding cases that no serious jurisprudence or philosophy of law could avoid asking with what general conception of the nature of law were such judicial powers compatible. Certainly American jurisprudence has not evaded this question, but in developing theories to explain-or explain away-this extraordinary judicial phenomenon, it has oscillated between two extremes with many intermediate stopping places. For reasons which I hope will become plain, I shall call these two extremes, respectively, the Nightmare and the Noble Dream.

\footnotetext{
* For the development of this doctrine see Allgeyer v. Louisiana, 165 U.S. 578 (1897) (fourteenth amendment "liberty of contract" prohibits state from regulating property owners" contracting for marine insurance with foreign insurance company); Lochner v. New York, 198 U.S. 45 (1905) (fourteenth amendment "liberty of contract" prohibits state from regulating the maximum hours per day or week a bakery employee may work); Adair v. United States, 208 U.S. 161 (1908) (fifth amendment "liberty of contract" bars federal prohibition of "yellow dog" employment contracts for employees of interstate railroads); Copprge v. Kansas, 236 U.S. 1 (1915) (fourteenth amendment "liberty of contract" bars state prohibition of "yellow dog" employment contracts); Adkins v. Children's Hosp., 261 U.S. 525 (1923) (fifth amendment "liberty of contract" prohibits District of Columbia from prescribing minimum wages for women).
} 
I.

The Nightmare is this. Litigants in law cases consider themselves entitled to have from judges an application of the existing law to their disputes, not to have new law made for them. Of course it is accepted that what the existing law is need not be and very often is not obvious, and the trained expertise of the lawyer may be needed to extract it from the appropriate sources. But for conventional thought, the image of the judge, to use the phrase of an eminent English Judge, Lord Radcliffe, is that of the "objective, impartial, erudite, and experienced declarer of the law," not to be confused with the very different image of the legislator. The Nightmare is that this image of the judge, distinguishing him from the legislator, is an illusion, and the expectations which it excites are doomed to disappointment-on an extreme view, always, and on a moderate view, very frequently. Certainly a clear-eyed scrutiny of the course of American constitutional decision seems to support the Nightmare view of things and suggests to an Englishman a cynical interpretation of de Tocqueville's observation that political questions in the United States sooner or later become judicial questions. "Perhaps they do so," the Englishman may say, "but the fact that they are decided in American law courts by judges does not mean that they are not there decided politically. So, if your Constitution has made law of what elsewhere would be politics, it has done so at the risk of politicising your courts."

So an Englishman habituated to the less spectacular activities of the English courts is tempted to agree with the many contemporary and later American jurists who accused the Justices of acting as a third legislative chamber when, in the first great period of the Supreme Court's activism between the Civil War and the New Deal, they ruled unconstitutional, under the due process clause, social and economic welfare legislation of every sort, statutes fixing maximum hours, minimum wages, price controls, and much else. ${ }^{10}$ The Justices of that period, according to their many critics, were availing themselves of conventional myths about the judicial process to pass off their personal political and economic doctrine of laissezfaire and to erect a Magna Carta for American big business as if this was the impartial application of determinate legal provisions, some. how already latent in the phrase "due process" and supposedly

- Radcliffe, The Path of the Law from 1967, at 14 (1968).

10 See note 8 supra. 
above the level of politics or merely political judgment. But economic liberties are not the only form of liberty, and in its second modern period of activism in our own day the courts' use of their powers of judicial review to effect major law reforms, which in other countries have been brought about, if at all, only after bitterly fought parliamentary battles, has provided a different series of examples to support the Nightmare view of the judicial process as mere crypto-legislation. To an Englishman the most striking modern instance is the Court's decision in 1973 sweeping away centuryold legislation against abortion in many states of the union on an issue where much moral opinion was against reform. "It achieved at a single judicial blow more than the last of eight English parliamentary struggles over a period of fifty years secured in my country. And this was done in the name of a right of the mother to privacy which is nowhere mentioned in the Constitution but was read into the due process clause as a fundamental liberty. Justice Oliver Wendell Holmes, in a famous dissenting opinion, protested against the laissez-faire decisions of his day that the fourteenth amendment had not enacted Herbert Spencer's Social Statics and its laissezfaire philosophy. ${ }^{12} \mathrm{Had}$ he survived into the modern period he might have protested that the fourteenth amendment had not enacted John Stuart Mill's On Liberty.

Given this history, it is not surprising that one great branch of American jurisprudential thought should be concerned to present the Nightmare view that, in spite of pretensions to the contrary, judges make the law which they apply to litigants and are not impartial, objective declarers of existing law. All this is comprehensible to the English lawyer after he has acquainted himself with the relevant constitutional history. What remains surprising is that in some variations of this jurisprudence the Nightmare view should be presented by serious American jurists not merely as a feature of certain types of difficult adjudication-as in the case of constitutional adjudication in which hugely general phrases like "due process" or "equal protection of the laws" have somehow to be fitted to particular cases-but as if adjudication were essentially a form of lawmaking, never a matter of declaring the existing law, and with the suggestion that until this truth was grasped and the conventional myths that obscured it dissipated, the nature of law could not

" Roe v. Wade, 410 U.S. 113 (1973); Doe v. Bolton, 410 U.S. 179 (1973).

${ }^{12}$ Lochner v. New York, 198 U.S. 45, 75 (1905) (Holmes, J., dissenting). 
be understood. I have said that serious jurists wrote as if this were the case, not that they believed it; for I agree with the recent historian of what is called the American Realist Movement of the 1920's and 1930's, with which the Nightmare view is most identified, that many who seemed to preach this message and send it forth in bold provocative slogans almost always meant something far less extravagant than what the slogans seemed to say. ${ }^{13}$ This is certainly true of Holmes' famous remark that " $t$ ] he prophecies of what the courts will do in fact and nothing more pretentious, are what I mean by the law." It is also doubtless true of Karl Llewellyn's "[w]hat [judges] do about disputes is . . . the law itself," though it is scarcely possible to take the same view of Jerome Franks' Law and the Modern Mind, ${ }^{15}$ hailed as a classic in the 1930 's, in which the belief that there could be legal rules binding on judges and applied by them, not made by them, in concrete cases is stigmatised as an immature form of fetishism or father fixation calling for psychoanalytical therapy.

Holmes certainly never went to these extremes. Though he proclaimed that judges do and must legislate at certain points, he conceded that a vast area of statutory law and many firmly established doctrines of the common law, such as the. requirement of consideration for contracts, and the demands of even the comparatively loose American theory of binding precedent, were sufficiently determinate to make it absurd to represent the judge as primarily a lawmaker. So for Holmes the judge's lawmaking function was "interstitial."16 Holmes' theory was not a philosophy of "full steam ahead and damn the syllogisms."

Nonetheless, in a way which an English jurist finds puzzling and without parallel in his own literature, the drive towards the Nightmare vision of the judicial process as a legally uncontrolled act of lawmaking has at times figured largely in American legal theory even though the writers caught up in it have often modified it in the face of recalcitrant facts. A most striking example of the hold of this theory on American juristic thought is John Chipman Gray's The Nature and Sources of the Law, which first appeared in 1909. This is much more like an English textbook on jurisprudence covering

\footnotetext{
13 See W. Twining, Karl Llewellyn and the Realist Movement 380 (1973).

" Holmes, The Path of the Law, supra note 2, at 173.

is See J. Frank, LaW and the Modern Mind 175, 178, 193, 203, 244, 264 (1930).

is Southern Pacific Co. v. Jensen, 244 U.S. 205, 221 (1917) (Holmes, J., dissenting).
} 
many different topics than any other American book, and the author, a distinguished Harvard lawyer, had been exposed to and acknowledged the influence of Bentham and Austin. Like an English book it surveys a wide range of topics-legal rights and duties, statutes, precedents, equity, law and morals-but it pursues throughout these topics a most un-English theme: that the law consists of the rules laid down by the courts used to decide cases and that all else, statutes and past precedents included, are merely sources of law. For this theory the words of the eighteenth-century Bishop Hoadly are three times invoked in support: "Whoever hath an absolute authority to interpret any written or spoken laws, it is he who is truely the Law-giver to all intents and purposes, and not the person who first wrote or spoke them."17 It is true that even in Gray's book this radical theme is blurred by inconsistencies and concessions to ordinary ways of thought and expression, as if common sense will out even in a work of jurisprudence. But the fact that an extremely able lawyer of great practical as well as academic experience should have committed himself so far to such a method of expressing general views about the nature of law manifests the strong hold on the American legal imagination of the Nightmare view of things.

Intertwined with the Nightmare there is another persistent theme. Perhaps the most misused quotation from any American jurist is Holmes' observation of 1884 that "[t]he life of the law has not been logic: it has been experience." 18 This in its context was a protest against the rationalist superstition (as Holmes thought it) that the historical development of the law by courts could be explained as the unfolding of the consequences logically contained in the law in its earlier phases. Judicial change and development of the law were, Holmes insisted, the expression of judges' "instinctive preferences and inarticulate convictions" in response, as he said, to the "felt necessities" 20 of his time. And his protest was made to secure a conscious recognition by lawyers of the legislative powers of the courts so that judicial change and readjustment of the law should be made after an explicit weighing of what he termed "considerations of social advantage."21 But by one American philosopher-historian, Professor Morton White, Holmes' remarks

\footnotetext{
17 J.C. Gray, supra note 3, at 102, 125, 172.

"s O.W. Holmes, The Conmon Law 1 (1881).

19. Id. at 36 .

Id. at 1.

21 Holmes, The Path of the Law, supra note 2, at 184.
} 
about logic have been taken as an example of a great movement of American thought which he terms the "Revolt against Formalism," and Holmes, together with John Dewey in philosophy, Thorsten Veblen in economics, and others, is taken as an example of a great reaction against excessive reliance on thought that is deductive, formal, abstract, or split into firmly separated distinct disciplines. ${ }^{22}$ The revolt was born of a wish to cross sterile, arbitrary, academic divisions and to substitute for formalism a vivid, realistic attention to experience, life, growth, process, context, and function. Whatever the truth of this interesting piece of American cultural history, attacks on "logic" or the "excessive use" of logic in the hands of some American jurists discussing judicial reasoning became, at any rate for the English jurist trying to understand the American scene, a most confusing and confused theme. Thus the laissez-faire interpretation of the due process clause of the Constitution, erecting freedom of contract into an almost absolute principle and striking down in its name much progressive social welfare legislation, was stigmatised as an example of the vices of formalism, black letter law, and excessive use of logic or'of "slot machine" or mechanical jurisprudence..$^{23}$ But logic does not of course dictate the interpretation of laws or of anything else, and no reliance upon it, excessive or otherwise, could account for the Supreme Court at the period in question reading into the Constitution the doctrines of laissez-faire. But what the critics were attacking in this confused way was really not the method by which the courts had arrived at their interpretations of the Constitution but the freezing of any single interpretation of any rule of law into a fixed premise, immune from revision and to be used in all further cases of its application. So they denounced, waving the banner of pragmatism, a purely backward-looking style of adjudication according to which particular decisions in particular cases owed their legal justification exclusively to their relation to the predetermined meaning of existing legal rules; and they urged upon judges a forward-looking form of adjudication according to which legal rules are treated as displaceable presumptions or working hypotheses, to be modified or rejected if the predictable consequences of their application in a shifting social context proved unsatisfactory. ${ }^{24}$

22 M. White, Social Thought in America: The Revolt Against Formalism (2d ed. 1957).

- See, e.g., Pound, Mechanical Jurisprudence, 8 Colum. L. Rev. 605, 609-10, 616 (1908).

2 See Dewey, Logical Method and Law, 10 Cornell L. Rev. 17 (1924). 
The themes I have described, though originating earlier, all figured in the 1920's and 1930's in the movement called Legal Realism. ${ }^{25}$ But in what did the realism of the realists consist? I find it very difficult to say because this active group of jurists differed from as much as they resembled each other. All, certainly, where concerned to stress the legislative opportunities of the courts and to dissipate the myths of conventional thought which they believed obscrued this. Some accompanied this with a tough-minded insistence that to understand law all that mattered was what courts did and the possibility of predicting this, not what paper rules said and not the reasons given by judges for their decisions. Some claimed that knowledge of the judge's character, habits of life, political, social, or economic views, even the state of his health, was at least as important a basis for successful prediction of a decision as legal doctrine. Others cherished a vision of a down-to-earth, truly scientific jurisprudence, inspired by the belief that the only profitable, or even the only rational, study of the law was investigations, using the methods of the natural sciences, into the course of judicial decision and its effects on men's behaviour.

What did all this amount to? Seen from afar it appears to many English jurists not to have advanced legal theory far or to have added much to the stock of valuable jurisprudential ideas. But the virtues and beneficent influence of the realist movement lay elsewhere. For the English lawyer the best work of the less extreme realists was not found in explicit general theorising about the nature of law and adjudication, but was often implicit in their writings on many different branches of the substantive law. This had a large and still visible influence on the style of adjudicaton in American courts and upon legal education which at any rate some English lawyers now much envy. For its main effect was to convince many judges and lawyers, practical and academic, of two things: first, that they should always suspect, although not always in the end reject, any claim that existing legal rules or precedents were constraints strong and complete enough to determine what a court's decision should be without other extra-legal considerations; sec-

${ }^{25}$ For general accounts of the legal realist movement see W. Rusiale, AuIERJCAN LEGal Realism (1968); G. Tarello, Il Renlismo Giuridico aliericano (1962); W. Thisidic, Karl LLEWELLYN AND THE REALIST MOVEMENT 70 (1973) (endorsing Llewellyn's protest-see Llewellyn, Some Realism About Realism-Responding to Dean Pound, 44 HARv.L. Rev. 1222 (1930), reprinted in K. Llewelly,, Jurisprudence, RealisM in Theory aNd Practice 42 (1962)-ggainst alleged misrepresentation by Pound and others). 
ondly, that judges should not seek to bootleg silently into the law their own conceptions of the law's aims or justice or social policy or other extra-legal elements required for decision, but should openly identify and discuss them.

II.

I turn now to the opposite pole which I have called the Noble Dream. Like its antithesis the Nightmare, it has many variants, but in all forms it represents the belief, perhaps the faith, that, in spite of superficial appearances to the contrary and in spite even of whole periods of judicial aberrations and mistakes, still an explanation and a justification can be provided for the common expectation of litigants that judges should apply to their cases existing law and not make new law for them even when the text of particular constitutional provisions, statutes, or available precedents appears to offer no determinate guide. And with this goes the belief in the possibility of justifying many other things, such as the form of lawyers' arguments which, entertaining the same expectations, are addressed in courts to the judges as if he were looking for, not creating, the law; the fact that when courts overrule some past decision, the later new decision is normally treated as stating what the law has always been, and as correcting a mistake, and is given a retrospective operation; and finally, the fact that the language of a judge's decision is not treated, as is the language of a statute, as the authoritative canonical text of a lawmaking verbal act.

Of course the Declaration of Independence spoke the language of universal natural rights and of a universal natural law. And the conception that behind or above positive law there is a universal natural law discoverable by human reason and applicable to all men at all times and places has indeed had its place in American jurisprudence, especially in the early years of the republic. Though I might add that its importance is not to be judged by the fact that the journal which began life as the Natural Law Forum now calls itself the American Journal of Jurisprudence. But, perhaps surprisingly, the Noble Dream, that even when a particular provision of the positive law is indeterminate there is nonetheless an existing law somewhere which judges can and should apply to dispose of the case, does not, in the work of the most renowned American jurists, take the form of an invocation of a universal natural law. The American Noble Dream has generally been that of something not universal, but specifically related to the concerns and shape of an individual legal system and the specific ends and values pursued 
through law in a particular society.

This particularist idea, that guidance for a particular society must, as Llewellyn said, "plant its feet"28 in that society and its actual practices, is one feature common to all forms of the American Noble Dream. Another common feature is a rejection of a belief which has sustained the Nightmare view of adjudication. This is the belief that, if a particular legal rule proves indeterminate in a given case so that the court is unable to justify its decision as the strict deductive conclusion of a syllogism in which it appears as a major premise, then the decision which the court gives can only be the judge's legally uncontrolled choice. Llewellyn attacked this belief when, in pleading for a "grand style" of judicial decision, he denounced as a blinding error the assumption that if the outcome of a law case is not, as he termed it, "foredoomed in logic," 27 it can only be the product of the judge's uncontrolled will. So a judge faced with the indeterminacy of a particular legal rule does not have as his only recourse what Holmes called the "sovereign prerogative of choice."2s $\mathrm{He}$ is not at once forced into the position of a lawmaker, even an interstitial lawmaker. The illusion that he is so forced is due to a failure to give proper weight to the fact that legal decisionmaking does not proceed in vacuo but always against a background of a system of relatively well established rules, principles, standards, and values. By itself, a given legal provision in its paper formulation may give no determinate guidance, but in the whole system of which the given provision is a member there may be, either expressed or latent, principles which, if consistently applied, would yield a determinate result.

Both the features which I have mentioned-which we might call particularism and holism-are to be found, with much else, in the work of Roscoe Pound, whose gigantic production, extending across seventy years of research, culminated in the publication in 1959, when the author was 89 , of a 3,000-page work on jurisprudence..$^{20}$ In the 1920's Pound introduced the notion, much stressed and further developed by other jurists, that a legal system was too narrowly conceived if it was represented as containing only rules attaching closely defined legal consequences to closely defined, detailed fac-

\footnotetext{
23 K. Llewellyn, Jurisprudence, Realisat in Theory and Practice 114 (1962).

27 K. Llewellyn, The Common Law Tradition, Deciding Appeals 4 (1960).

2 Holmes, Law in Science and Science in Law, in O.W. Holsres, Collected Legal Papers 239 (1920).

a R. POUND, JURISPRUdENCE (1959).
} 
tual situations and enabling decisions to be reached and justified by simple subsumption of particular cases under such rules. ${ }^{30}$ Besides rules of this kind, legal systems contain large-scale general principles; some of these are explicitly acknowledged or even enacted, whereas others have to be inferred as the most plausible hypotheses explaining the existence of the clearly established rules. Such principles do not serve merely to explain rules in which they are manifested but constitute general guidelines for decision when particular rules appear indeterminate or ambiguous or where no relevant authoritative, explicitly formulated rule seems available. Courts should not consider themselves free to legislate for such cases, not even in accordance with their conceptions of justice or social good, but should instead search in the existing system for a principle or principles which singly or collectively will both serve to explain the clear existing rules and yield a determinate result for the instant case.

To an English lawyer this suggested recipe for the elimination of judicial choice may seem to make too much of, or to hope for too much from, a much admired style of adjudication followed by some great English common law judges. In the most famous modern instance, Lord Atkin, in our House of Lords, faced the question whether a manufacturer was liable to a consumer with whom he stood in no contractual relationship for injuries caused by a negligently manufactured product. In this famous English case, Donoghue $v$. Stevenson, the product was a bottle of ginger beer containing the toxic remnants of a dead snail. Before this decision the situations in which one person was liable to another for injuries caused by his carelessness were the subject of a number of separate rules specifying relationships where what the English lawyer calls "a legal duty of care" was said to exist. Such rules specified, for example, the liability of owners or occupiers of premises to persons coming upon them, of parties standing in contractual relationships, and of persons using the highways, but did not include nor plainly exclude the liability of a manufacturer to a consumer with whom he had no contract. Nor was there any clear explicit principle stating in general terms what was common to all these cases showing the general considerations that established whether or not a relationship gave rise to a duty. Lord Atkin in this leading case ruled that the manufacturer was liable under the broad principle that

so See Pound, The Theory of Judicial Decision, 36 Harv. L. REv. 641 (1923). 
whoever undertakes any activity which may forseeably be harmful to those who are likely to be affected by it must take reasonable care to avoid inflicting foreseeable harm on those who are their neighbours, so understood. Though pinched and narrowed in subsequent cases, this broad principle, when first enunciated by Lord Atkin, served both to define the relationships and so explain the already established clear rules and to provide an answer in the instant unsettled case.

This style of decision is characteristic of the general holistic approach urged by Pound and later jurists whose theories of adjudication at least approximate the Noble Dream, and is enough to refute superficial theories that when a particular legal rule proves indeterminate the judge can only then push aside his law books and proceed to legislate. But plainly, merely to adopt this style of decision is not in itself sufficient to banish the Nightmare. Many questions arise. May not the legal system contain conflicting principles? May not a given rule or set of specific rules be equally well explained by a number of different alternative hypotheses? If so, will there not be need at these higher levels for judicial choice, and if so, will not adjudication still fall short of the Noble Dream since such a choice will be an act of lawmaking, not a further discovery of existing law? Pound in his long life addressed himself intermittently to such questions, and one of his answers seems to have been that, at still higher levels of the legal system above that of principles, there are the received values or ideals of the system, again either explicitly acknowledged or inferable from its established rules and principles, and that recourse to these would suffice to determine which of a number of conflicting or alternative principles should prevail. But of course the same questions could be pushed further. Will not the same conflicts or alternatives present themselves at this highest level of received values or ideals? What are the grounds for thinking that there must be some unique resolution of such conflicts awaiting the judge's discovery and not calling for his choice? To be fair to Pound, it must be said that he probably conceived of the idea that a whole system with its principles and received values would provide a determinate, unique answer when particularly legal rules ran out, not as a literal truth about legal systems but rather as a regulative ideal for judges to pursue; this process would dictate a salutary style of judicial decision and operate as a powerful constraint upon judicial choice rather than eliminate altogether the need for such a choice. This relatively modest version of the Noble Dream as a constraint upon rather than as an always available substitute for 
judicial choice is, I think, in the end also the message preached by Karl Llewellyn in his rich and turbulent advocacy of what he termed the grand style of judicial decision. This message is presented not in general theoretical terms, for which he had a great distaste, but in the terminology of the craftsman. The judge, in cases where particular rules-paper rules as they are sometimes deprecatingly called-prove indeterminate, is to "carve" his decision with the "grain" of the system as a whole, ${ }^{32}$ that is, in accordance with its broad principles and established values. Faced with the indeterminacies of the positive law the judge is not simply to decide without further attention to the system, as he thinks best. This is the most important constraint upon judicial choice and what accounts for the high measure of predictability of judicial decision in appellate cases. I confess there is much in Llewellyn's writing on this subject which I do not fully understand in spite of the patient, lucid, and exhaustive examination of it by his sympathetic English interpreter, Professor Twining. ${ }^{33}$ I think, however, that in Llewellyn's version of the Noble Dream it is enough that when the judges choose, as they may have to, at the higher level of principles or received values, the alternatives presented to them at this level will all have the backing of great areas of the legal system comprehended under them, and so whichever alternative is chosen, it will have its feet firmly planted in the existing system and may be ranked as a decision warranted because controlled by law.

Professor Ronald Dworkin's contemporary version of the Noble Dream $^{34}$ does not make any such compromise on these points, and he is, if he and Shakespeare will allow me to say so, the noblest dreamer of them all, with a wider and more expert philosophical base than his predecessors, and he concentrates formidable powers of argument on the defence of his theory. His theory of adjudication is marked by stress on many new distinctions, such as that between arguments of principle about existing entitlements or rights, which he thinks it is the proper business of judges to use in support of

" [1932] A.C. 562.

32 See K. Llewelly, The Common law Tradition, supra note 27, at 222, where, in writing on "Appellate Judging as a Craft of Law," Llewellyn states that "I have tried to reach the idea in terms of working with rather than across or against the grain . . . . to carve with the grain ... to reveal the latent rather than to impose new form, much less to obtrude an outside will."

is See W. Twining, supra note 13.

"See Dworkin, Hard Cases, 88 Harv. L. Rev. 1057 (1975), reprinted in R. Dworkin, Takina RuGHTS SERIOUSLY 81 (1977). 
decisions, as contrasted with arguments of policy about aggregate welfare or collective goals, which are not the judge's business but the legislator's. Nonetheless his theory, in the senses I have already explained, is a holistic and particularistic one. Like Pound he rejects the idea that a legal system consists only of its explicit authoritative rules and emphasises the importance of implicit unformulated principles; and like Llewellyn he rejects the idea, which he attributes to positivist jurisprudence, that the judge must, when the explicit rules prove indeterminate, push aside his law books and start to legislate in accordance with his personal morality or conceptions of social good or justice.

So for. Dworkin, even in the hardest of hard cases where each of two alternative interpretations of a statute or two conflicting rules seems to fit equally well the already clearly established law, the judge is never to make law. So Oliver Wendell Holmes was, in Dworkin's view, wrong in claiming that at such points the judge must exercise what he called "the sovereign prerogative of choice" and must legislate even if only "interstitially." According to the new theory, the judge, however hard the case, is never to determine what the law shall be; he is confined to saying what he believes is the law before his decision, though of course he may be mistaken. This means that he must always suppose that for every conceivable case there is some solution which is already law before he decides the case and which awaits his discovery. He must not suppose that the law is ever incomplete, inconsistent, or indeterminate; if it appears so, the fault is not in it, but in the judge's limited human powers of discernment, so there is no space for a judge to make law by choosing between alternatives as to what shall be the law.

Of course on this view the judge has to present arguments for what he believes to be the law. Very often his reasoning will take just the form I have illustrated from the great English case on products liability. That is, he must construct a general principle which will both justify and explain the previous course of decision in relation to this subject matter and will also yield a definite answer for the new case. But of course that is only the start of his inquiry, for there may be a plurality of such general principles fitting equally well the existing law but yielding different solutions for the instant case. This position was reached in the English courts when the general principle announced by Lord Atkin in relation to negligence came

${ }^{35}$ Holmes, Law in Science and Science in Law, supra note 28, at 239. 
to be applied to cases of negligent misstatements on which persons had acted to their detriment. ${ }^{36}$ Professor Dworkin recognises that at any level of enquiry into the system and the general principles which may be said to be immanent in the existing law there may be unresolved questions of this sort. To deal with them the judge must, ideally at any rate, open up much wider ranging questions of justice and political morality. In Professor Dworkin's words, he

must develop a theory of the constitution, in the shape of a complex set of principles and policies that justify that scheme of government . . . . He must develop that theory by referring alternately to political philosophy and institutional detail. $\mathrm{He}$ must generate possible theories justifying different aspects of the scheme and test the theories against the broader institution. ${ }^{37}$

When the discriminating power of this, test is exhausted, he must "elaborate the contested concepts that the successful theory employs." 38 The judge thus must decide what conception of the fundamental values protected by the system, such as liberty or personal dignity or equality, is superior. Plainly this is a Herculean task and Professor Dworkin rightly calls the judge, whom he imagines embarked on the construction of such a theory, Hercules. He admits that different judges coming from different backgrounds may construct different and conflicting Herculean theories, and, when this is so, it cannot be demonstrated that one of these is uniquely correct and the others wrong. Indeed, all may be wrong. Nonetheless, to make sense of what they do, judges must believe that there is some single theory, however complex, and some single solution for the instant case derivable from it, which is uniquely correct.

Professor Dworkin's theory will, I am sure, much excite and stimulate both jurists and philosophers for a long time on both sides of the Atlantic. It has indeed already added much to the stock of valuable jurisprudential ideas. But if I may venture a prophecy, I think the chief criticism that it will attract will be of his insistence that, even if there is no way of demonstrating which of two conflicting solutions, both equally well warranted by the existing law, is correct, still there must always be a single correct answer awaiting

ss Mutual Life \& Citizens Assurance Co. v. Evatt, [1971] A.C. 793.

"7 Dworkin, Hard Cases, 88 HARv. L. Rev. 1057, 1085 (1975), reprinted in R. Dwonkin, Taking Rights Seriously 81, 107 (1977).

3x Id. 
discovery. Lawyers might think that if a judge has conformed before he decides to all those constraints which distinguish judicial lawmaking from lawmaking by a legislator, above all if he has considered conscientiously and impartially what Professor Dworkin well calls the "gravitational force" 39 of the clearly established law and has arrived at a conclusion as to which of the alternatives open to him is most fair or just, no purpose is served by insisting that if a brother judge arrives after the same conscientious process at a different conclusion there is a unique right answer which would show which of the two judges, if either, is right, though this answer is laid up in a jurist's heaven and no one can demonstrate what it is.

Similarly, philosophers may dispute the claim that as a matter of logical coherence anyone who attempts to answer a question of value, whether it be the question which of two legal answers to a litigant's claims is more just or fair, or which of two competitors in a beauty competition is more beautiful, or which of Shakespeare's comedies is the funniest, must, in order to give sense to such questions, assume that there is a single objective right answer in all such cases. The corollary in the case of law is that what litigants are always entitled to have from the judge is the right answer (though there is no means of demonstrating what it is), just as they would be entitled to have a right answer to the question which of two buildings is the taller, where of course the correctness of the answer can be demonstrated by a public objective test. Perhaps both philosophers and lawyers might agree with Professor Kent Greenawalt of Columbia Law School who, after a patient examination of Professor Dworkin's attack on the idea that judges have a discretion in hard cases, concludes that "[d]iscretion exists so long as no practi-" cal procedure exists for determining if a result is correct, informed lawyers disagree about the proper result, and a judge's decision either way will not widely be considered a failure to perform his judicial responsibilities." 10

Professor Dworkin's version of the Noble Dream challenges at two crucial points two themes which have dominated English jurisprudence ever since Jeremy Bentham, in the year of American Independence, laid its foundations when he published his first book." The first theme relates to the question just discussed. It is the insistence

30 Id. at 1089, Taking Rights Seriously at 111.

* Greenawalt, Discretion and Judicial Decision: The Elusive Quest for the Fetters that Bind Judges, 75 CoLuM. L. REv. 359, 386 (1975).

" J. Bentham, A Fragment on Government (1776). 
that, though the law may be at points incomplete or indeterminate, so far as it is determinate there are means of demonstrating what it is by reference to a legal system's criteria of validity or its basic provisions concerning the sources of law. All variants of English positivist jurisprudence subscribe to this view. The second theme dominating so much English jurisprudence is the utilitarian conception that both judges and legislators, in considering what the law ought to be, may and indeed must at many points take account of general utility and of what will most advance the general welfare. Even a judge, though subject to many constraints from which the legislature is free, may properly allow his decision between competing answers, each supported by the existing law, to be tipped by such utilitarian considerations. That is, he is not confined to asking what is the most fair or most just in accordance with distributive principles of justice. But for Professor Dworkin, a judge who thus steps into the area of what he calls policy, as distinct from principles determining individual rights, is treading forbidden ground reserved for the elected legislature. This is so because for him not only is the law a gapless system, but it is a gapless sytem of rights or entitlements of what people are entitled to have as a matter of distributive justice and not ever of what they should have because it is to the public advantage that they should have it. This exclusion of "policy considerations" will, I think, again run counter to the convictions of many lawyers that it is indeed perfectly proper and indeed at times necessary for judges to take account of the impact of their decision on the general community welfare. ${ }^{42}$

Professor Dworkin's exclusion of such considerations from the judge's purview is part of the general hostility to utilitarianism that characterises his work, and this point takes me back to my general theme. It seems to the English observer that, in the United States, utilitarianism is currently on the defensive in the face not only of Professor Dworkin's work but also of the two very important contributions to political philosophy made by Professor Rawls' Theory of Justice ${ }^{43}$ and Professor Nozick's Anarchy, State, and Utopia.44 These works have much affinity with the eighteenth-century doctrines of the unalienable rights of man. In any case utilitarianism as a critique of law and society has generally been overshadowed in America by doctrines of individual rights. Nonetheless, it has pene-

12 Others have reached the same conclusion. See Greenawalt, supra note 40, at 391; Note, Dworkin's "Rights Thesis" (John Umana), 74 Mich. L. Rev. 1167, 1179-83 (1976).

13 J. Rawls, A Theory of Justice (1971).

" R. Nozick, ANarchy, State, aNd Utopia (1974). 
trated, though not very far, into American theories of the judicial process. It has done this mainly in a form which leads easily into welfare economics, where the aggregate utility to be maximised is defined not in terms of pleasure, as in classical utilitarianism, but in terms of the satisfaction of expressed wants or revealed preferences. In this form it is to be found in scattered hints thrown out by Oliver Wendell Holmes that judges might soon have at their disposal to guide them in their necessary lawmaking tasks a science of law which would "determine, so far as it can, the relative worth of our different social ends" 45 or, as he also puts it, would establish the postulates of the law upon "accurately measured social desires," 15 and that this would replace the present inarticulate and intuitive methods of judicial lawmaking. In this context Holmes spoke of the man of the future as the man of statistics and as the master of economics..$^{17}$

A similar conception of science applied to law seems to underlie Pound's sociological jurisprudence and its attempt to analyse the conflicts which the law is called upon to resolve in terms of underlying interests, that is, in terms of wants or desires expressed as claims to legal recognition and enforcement. Many of the pages of this immensely prolific writer are dedicated to the classification of such interests as individual, social, and public. ${ }^{18}$ But coupled with this analysis is the conception of a science of social engineering which would show how conflicting interests might be ordered with what Pound calls the least friction or waste or with the least sacrifice of the total scheme of interests as a whole. ${ }^{49}$ To do this Pound acknowledges that there must be some method of weighing or valuing the conflicting items, and so some form of quantification, but his discussion does not provide it.

If these two flirtations with the idea of a science of lawmaking, whether by legislator or judge, rest on any coherent philosophy, it is that of utilitarianism. But utilitarianism is quite explicitly acknowledged as the inspiration of the contemporary Chicago-bred school of the economic analysis of law, ${ }^{50}$ which now has a great hold

${ }^{15}$ Holmes, Law in Science and Science in Law, supra note 28, at 242.

"Id. at 226.

"Holmes, The Path of the Law, supra note 2, at 187.

s3 3 R. POUNd, JuRisprudence 16-324 (1959).

i 1 R. Pound, Jurisprudence 545 (1959); 3 R. Pound, Junusprudence 330-31; R. Pound, justice According to LAW 3 (1951); R. Pound, Socinl Control Through LAw 64.65 (1942).

so See R. Posner, Economic Analysis of Law (1972). 
upon American teaching of the law of torts. This school of thought claims to have laid bare a profound relationship between law and economic order. As an explanatory theory it is the claim that great areas of the common law may be illuminatingly seen as mimicking an economic market, for many established legal rules are consistent with the conception of law as a system of incentives, used to ensure that economic resources are allocated to uses which are economically most efficient, where efficiency is defined as maximising aggregate want satisfaction. This is said to be the implicit economic logic of the law. But on its critical or normative side, the theory claims to provide a rational, impartial, and objective standard for the determination of legal disputes where the question is who should bear a loss. Thus, to take one of its simplest examples, for this theory the point of the imposition of legal liability for negligence causing harm to others is to provide an incentive to take economically justified, utility-maximising precautions against causing such harm, that is, precautions the cost of which is less than the loss caused by their neglect discounted by the probability of its occurrence. This theory of incentives runs strongly counter not only to Professor Dworkin's theory that the judge must not concern himself with considerations of general utility but also with the conventional idea that liability in negligence is at least sometimes imposed as a matter of justice between the parties, on the footing that the victim of another's negligence has a moral right to have his loss made good by the negligent party, so far as monetary compensation can do this. To the question why, if the law is only concerned with the provision of incentives, should not this be done by fines payable to the state, instead of by damages paid in private litigation to the victims, the theory returns the answer, which is perhaps more ingenious than convincing, that the latter (damages paid to the victim), in its turn, is an incentive for victims to bring cases of negligence to official notice, and that the result will be a far more effective deterrent than could be provided by any central criminal-law-type agency policing negligent conduct and imposing fines. ${ }^{51}$

No one who has read Professor Posner's elaborate and refined work and the large literature which has grown out of it, designed to establish these utilitarian underpinnings of the law, could fail to profit. This is not, I think, because it succeeds in its ostensible purpose, but because its detailed ingenuity admirably forces one to

\footnotetext{
st See Posner, A Theory of Negligence, 1 J. Legal Stud. 29, 48 (1972).
} 
think what else is needed besides a theory of utility for a satisfactory, explanatory, and critical theory of legal decisions. It becomes clear that in general what is needed is a theory of individual moral rights and their relationship to other values pursued through law, a theory of far greater comprehensiveness and detailed articulation than any so far provided.

In conclusion let me say this. I have protrayed American jurisprudence as beset by two extremes, the Nightmare and the Noble Dream: the view that judges always make and never find the law they impose on litigants, and the opposed view that they never make it. Like any other nightmare and any other dream, these two are, in my view, illusions, though they have much of value to teach the jurist in his waking hours. The truth, perhaps unexciting, is that sometimes judges do one and sometimes the other. It is not of course a matter of indifference but of very great importance which they do and when and how they do it. That is a topic for another time. 
